\title{
Minister proposes 'Richter' scale for nuclear accidents
}

\section{Paris}

Two years after the explosion of the nuclear reactor at Chernobyl, the French Industry Minister, Alain Madelin, has drawn up a 'scale of severity' to evaluate nuclear accidents. In common with other European governmments, the French have now learned that much of the reasssuring information put out soon after the Chernobyl incident was at best misleading and at times false. This has undermined public confidence in the large French nuclear power programme, and Madelin's new approach is intended to help allay public fears by making it possible for the layman to appreciate the degrees of risk involved.

Madelin's scale has six levels, defined essentially in terms of the extent of pollution risk. Operational anomalies without immediate hazard are covered by the two lowest. Level 1 means that operating norms have been exceeded, while Level 2 incidents could have serious repercussions if no action is taken. The recent sodium leak in the Superphénix reactor would have been Level 2 .

Level 3 covers incidents where radioactive substances are leaked at concentrations over 10 per cent of the permitted annual threshold, or where containment structures are damaged. At Level 4, leaked radiation would reach authorized levels, or would imply medical attention for those affected. Also at this level are accidents to the reactor core itself.

At Level 5 and Level 6 the risk is no longer confined to the reactor site. The severity of the risk is defined by the level of leaked radiation-either tens of thousands of curies (Level 5) or hundreds of thousands of curies (Level 6).

Given the difficulties encountered, even within the European Community, in establishing what levels of radiation are 'safe', Madelin's scale has been criticized as giving a false image of objectivity. And the public is still at the mercy of a government's readiness to supply accurate and timely information in the event of a nuclear accident, however the information is expressed.

Peter Coles

\section{Atomic energy research 'under threat' from privatization \\ London}

FURTHER warnings were sounded last week about the threat to research posed by the British government's plans to privatize the electricity supply industry. The United Kingdom Atomic Energy Authority, whose chief function is to carry out research and development in support of the nation's nuclear power programme, is particularly concerned that during the period leading up to the sell-off and when the industry is in private hands, cash for the fast reactor programme will dry up.

Giving evidence to a House of Lords select committee last week, the authority's chairman, John Collyear, said that uncertainties about the future responsibilities of a privately-owned electricity supply industry made planning difficult. Furthermore, he envisaged problems arising over the money that will be made available for underlying basic research. At present the authority's principal customers, the Department of Energy and the Central Electricity Generating Board (CEGB), allow 6 per cent of their spending to be used for basic research. The government proposes to sell off the CEGB in two lots-one retaining 70 per cent of generating capacity, including the nuclear power capability, and the other with $\mathbf{3 0}$ per cent. Collyear is concerned that both companies, especially the non- nuclear company, would be reluctant to support the authority's work voluntarily.

Already the CEGB has pulled out of two authority-led research programmes, possibly because of impending privatization (see Nature 332, 382; 1988). The government's stated plans make no specific mention of research. The authority believes that the new structure of the industry should provide "fresh opportunities" for the authority to provide services. "But it is not likely that new entrants to the industry will be strong enough to sponsor research and development into longer-term advanced nuclear (or non-nuclear) technologies"'. The authority proposes funding through a levy on electricity sales or by subscriptions from companies.

Britain's principal centre for fast reactor research is at Dounreay in Scotland. The site operates a $250 \mathrm{MW}$ prototype fast reactor, and an associated reprocessing plant. The reactor is unique among prototype fast reactors in having a facility for testing full-scale commercial fast reactor fuel, which can then be reprocessed at the nearby plant. The authority is waiting for permission from the government to sign a collaborative agreement with four European partners to build a full-scale demonstration reactor.

\section{Indian ambitions}

The Indian government is hoping to be invited to collaborate with the United States on the Superconducting Super Collider (SSC) project because, says Science Minister K. R. Narayanan, "participation in this experiment will benefit our country especially in the fields of highenergy particle physics and open up new areas in the frontiers of science".

Talks on Indian participation were held recently between Leon Lederman, director of Fermilab, and high-energy physicists from the Bhabha Atomic Research Centre and the Tata Institute of Fundamental Research in Bombay. Lederman said that a number of suggestions have been made but details have yet to be worked out. According to Lederman, one possible area of collaboration is in devices and equipment such as high-vacuum systems and superconducting correction coils.

Because of cheap labour, auxiliary equipment for the SSC could be made in India at low price. Indian physicists feel that the technology and experience they would gain in fabricating SSC components would be helpful in their own accelerator programme.

K. S. J.

Although the US Department of Energy has made a general appeal to other countries to contribute to the SSC, both financially and in kind, collaboration on magnet building would require cooperation between industrial manufacturers as well as governments. Because one of the postulated benefits of SSC is to help American industry, the possibility of joint ventures in building SSC has been regarded with some ambivalence. D.L.

\section{Canadian submarines}

US President Ronald Reagan last week told visiting Canadian Prime Minister Brian Mulroney that he will allow Canada to use secret US nuclear submarine propulsion technology. Canada is considering buying a fleet of nuclear submarines from either Britain or France. Purchase of British "Trafalgar" nuclear attack subma. rines requires permission from the United States as they use US-designed power plants. President Reagan's decision is ironic in that Canada was prompted to buy submarines by a dispute with the United States over the sovereignty of the Arctic North-West passage. A.A.

\section{Boyer/Cohen award}

A NEW prize for discovery in 'pure or applied science in the field of biotechnology' has been endowed by two famous French names: Moet Henessy and Louis Vuitton. The first prize goes to Herbert W. Boyer and Stanley N. Cohen for their pioneering work in genetic engineering. Valued at FF500,000 $(£ 50,000)$, the award will be presented on $5 \mathrm{July}$ at a conference at the Institut de la Vie, near Paris. P.C. 